\title{
Bioremediation of Bisphenol A by Glycosylation with Immobilized Marine Microalga Amphidinium crassum
}

\author{
—Bioremediation of Bisphenol A by Immobilized Cells
}

\author{
Kei Shimoda ${ }^{1^{*}}$, Ryohei Yamamoto ${ }^{2}$, Hiroki Hamada ${ }^{2^{*}}$ \\ ${ }^{1}$ Department of Chemistry, Faculty of Medicine, Oita University, Oita, Japan \\ ${ }^{2}$ Department of Life Science, Faculty of Science, Okayama University of Science, Okayama, Japan \\ E-mail: "shimoda@med.oita-u.ac.jp, ${ }^{*}$ hamada@dls.ous.ac.jp \\ Received April 14, 2011; revised May 17, 2011; accepted May 26, 2011
}

\begin{abstract}
Glycosylation of bisphenol A, which is an endocrine disrupting chemical, was investigated using immobilized marine microalga and plant cells from the viewpoint of bioremediation of bisphenol A. Immobilized marine microalga of Amphidinium crassum glucosylated bisphenol A to the corresponding glucoside. On the other hand, bisphenol A was glycosylated to its glucoside, diglycoside, gentiobioside, and gentiobiosylglucoside, which was a new compound, by immobilized plant cells of Catharanthus roseus.
\end{abstract}

Keywords: Glycosylation, Biosphenol A, Amphidinium crassum, Catharanthus roseus, Immobilized Cells

\section{Introduction}

Bisphenol A is widely used as the starting material for the production of polyacrylates, ether resins, phenol resins, photostabilizers, insecticides, fragrance ingredients, agricultural chemicals, pharmaceuticals, and coatings, and are released as pollutants and toxic compounds into rivers and seas [1]. Recently, bisphenol A has attracted considerable attention as it exhibited estrogenic activity in bioassays [2] and has been listed among "chemicals suspected of having endocrine disrupting effects" by the World Wildlife Fund, the National Institute of Environmental Health Sciences in the USA and the Japanese Environment Agency. From the viewpoint of pollution control, many studies on the biological metabolites of aromatic compounds have been reported, e.g., the benzene rings of aromatic compounds are degraded through the gentisic acid intermediate by some soil bacteria [3-8]. However, little attention has been paid to the biological degradation of endocrine disrupting chemicals. On the other hand, the metabolic pathway of aromatic compounds in plant cells is quite different from that in microorganisms; plant cells glycosylate phenols and accumulate them as glycosides in the cells [9-15].

Recently, the biotransformation of exogenous substrates by cultured marine microalga and plant cells has been reported [16,17]. These cells have the abilities of hydroxylation, glycosylation, oxido-reduction, hydrogena- tion, and hydrolysis for various organic compounds. Particularly, glycosylation seems to be an efficient procedure for the bioremediation of environmental pollution, because the estrogenicity of endocrine disrupting compound, i.e., bisphenol $\mathrm{A}$, was eliminated by formation of its glycosides [18]. This paper describes the glycosylation of bisphenol A by the immobilized marine microalga of Amphidinium crassum and immobilized plant cells of $\mathrm{Ca}$ tharanthus roseus.

\section{Experimental}

\subsection{General}

Bisphenol A was purchased from Aldrich Chemical Co. The ${ }^{1} \mathrm{H}$ and ${ }^{13} \mathrm{C}$ NMR, H-H COSY, C-H COSY, and $\mathrm{HMBC}$ spectra were recorded in $\mathrm{CD}_{3} \mathrm{OD}$ using a Varian XL-400 spectrometer (Varian Inc.). The chemical shifts were expressed in $\delta(\mathrm{ppm})$ referring to tetramethylsilane. The FABMS spectra were measured using a JEOL MStation JMS-700 spectrometer (JEOL Ltd.). HPLC was carried out on a YMC-Pack R\&D ODS column (150 $\times 30 \mathrm{~mm})$ at $25^{\circ} \mathrm{C}$ [solvent: methanol-water $(9: 11, \mathrm{v} / \mathrm{v})$; detection: UV $(280 \mathrm{~nm})$; flow rate: $1.0 \mathrm{ml} / \mathrm{min}$ ].

\subsection{Cell Line and Culture Conditions}

A. crassum, a gift from Ehime Prefectural Fisheries Ex- 
perimental Station, Japan, cells were cultivated in a synthetic seawater $(500 \mathrm{ml})$ for 2 weeks at $20^{\circ} \mathrm{C}$ with constant aeration by air $(1 \mathrm{l} / \mathrm{min})$ in 11 flasks under illumination $(1000 \mathrm{~lx})$. The synthetic seawater contained 20.747 $\mathrm{g} \mathrm{NaCl}, 0.8 \mu \mathrm{g} \mathrm{MnCl}_{2} \cdot 4 \mathrm{H}_{2} \mathrm{O}, 9.474 \mathrm{~g} \mathrm{MgCl}_{2} \cdot 6 \mathrm{H}_{2} \mathrm{O}, 1.326$ $\mathrm{g} \mathrm{CaCl} \cdot 6 \mathrm{H}_{2} \mathrm{O}, 3.505 \mathrm{~g} \mathrm{Na}_{2} \mathrm{SO}_{4}, 597 \mathrm{mg} \mathrm{KCl}, 171 \mathrm{mg}$ $\mathrm{NaHCO}_{3}, 85 \mathrm{mg} \mathrm{KBr}, 34 \mathrm{mg} \mathrm{Na} \mathrm{B}_{4} \mathrm{O}_{7} \cdot 10 \mathrm{H}_{2} \mathrm{O}, 12 \mathrm{mg} \mathrm{SrCl}$, $3 \mathrm{mg} \mathrm{NaF}, 1 \mathrm{mg} \mathrm{LiCl}, 0.07 \mathrm{mg} \mathrm{KI}, 0.2 \mu \mathrm{g} \mathrm{CoCl}{ }_{2} \cdot 6 \mathrm{H}_{2} \mathrm{O}, 8$ $\mu \mathrm{g} \mathrm{AlCl} \cdot 6 \mathrm{H}_{2} \mathrm{O}, 5 \mu \mathrm{g} \mathrm{FeCl} \cdot 6 \mathrm{H}_{2} \mathrm{O}, 0.2 \mu \mathrm{g} \mathrm{Na} \mathrm{WO}_{4} \cdot 2 \mathrm{H}_{2} \mathrm{O}$, $0.02 \mathrm{mg}\left(\mathrm{NH}_{4}\right)_{6} \mathrm{Mo}_{7} \mathrm{O}_{24}, 0.0045 \% \mathrm{Na}_{2} \mathrm{SiO}_{3}$ and $1.07 \mathrm{ml}$ of NM solution per 11 of distilled water. The NM solution (1 l) is a kind of vitamin solutions and composed of $\mathrm{NaNO}_{3}(150 \mathrm{~g}), \mathrm{Na}_{2} \mathrm{HO}_{4}(10 \mathrm{~g})$, EDTA-2Na (0.9 g), Vitamin $\mathrm{B}_{12}(1.5 \mathrm{mg})$, thiamine $\mathrm{HCl}(75 \mathrm{mg})$, biotin $(1 \mathrm{mg})$, EDTA-Fe $(2.5 \mathrm{~g})$, and $\mathrm{H}_{2} \mathrm{NC}\left(\mathrm{CH}_{3} \mathrm{OH}\right)_{3}(5 \mathrm{~g})$ in distilled water.

The cultured plant cells of $C$. roseus have been cultivated over 20 years in our laboratory and subcultured in $300 \mathrm{ml}$ conical flasks containing Schenk and Hildebrand (SH) medium $(100 \mathrm{ml}, \mathrm{pH} 5.7)$ on a rotary shaker (120 $\mathrm{rpm})$ at $25^{\circ} \mathrm{C}$ in the dark for every 3 - 5 weeks. Part of the callus tissues (fresh weight $30 \mathrm{~g}$ ) was transplanted to freshly prepared $\mathrm{SH}$ medium $(100 \mathrm{ml}$ in a $500 \mathrm{ml}$ conical flask, $\mathrm{pH}$ 5.7) containing $3 \%$ sucrose and was incubated for 3 weeks prior to use for this work.

\subsection{Glycosylation of Bisphenol A by A. crassum and $C$. roseus}

Cultured $A$. crassum cells were harvested by centrifugation at $3000 \mathrm{rpm}$ for $15 \mathrm{~min}$ and washed twice by adding $100 \mathrm{ml}$ of synthetic seawater followed by centrifugation (3000 rpm for $15 \mathrm{~min}$ ). To the $500 \mathrm{ml}$ flask containing 9 $\mathrm{g}$ of cultured $A$. crassum cells and $300 \mathrm{ml}$ of a synthetic seawater was added $0.2 \mathrm{mmol}$ of bisphenol A. The cultures were incubated at $20^{\circ} \mathrm{C}$ on a rotary shaker $(120$ $\mathrm{rpm}$ ) for five days under illumination (1000 lx). After the incubation period, the cells and synthetic seawater were separated by centrifugation at $1000 \mathrm{~g}$ for $15 \mathrm{~min}$. The synthetic seawater was extracted with ethylacetate and then $n$-butanol. The cells were extracted (three times) by homogenization with methanol, and the methanol fraction was concentrated and partitioned between water and ethylacetate. The ethylacetate fractions were analyzed by HPLC, combined, and concentrated. The water and $n$ butanol fractions were analyzed by HPLC, combined, evaporated, and re-dissolved in water. This water fraction was applied to a Diaion HP-20 column and the column was washed with water followed by elution with methanol. The methanol eluate was subjected to preparative HPLC [column: CAPCELLPAK R\&D C18 column (250 $\times 30 \mathrm{~mm}$ ); solvent: $\mathrm{MeOH}: \mathrm{H}_{2} \mathrm{O}(9: 11$, v/v); detection: UV (340 nm); flow rate: $1.0 \mathrm{ml} / \mathrm{min}$ ] to give glycosyla- tion products.

Bisphenol A $(0.2 \mathrm{mmol})$ was administered to the 500 $\mathrm{ml}$ flask containing $300 \mathrm{ml}$ of SH medium and $70 \mathrm{~g}$ of the suspension cultured cells of $C$. roseus, and the cultures were incubated at $25^{\circ} \mathrm{C}$ for five days on a rotary shaker (120 rpm) under illumination (1000 lx). After the incubation, the cells and medium were separated by filtration with suction. The filtered medium was extracted with EtOAc. The medium was further extracted with $n$ $\mathrm{BuOH}$. The cells were extracted (x3) by homogenization with $\mathrm{MeOH}$. The $\mathrm{MeOH}$ fraction was concentrated and partitioned between $\mathrm{H}_{2} \mathrm{O}$ and EtOAc. The EtOAc fractions were combined and concentrated. The $\mathrm{H}_{2} \mathrm{O}$ fraction was applied to a Dianion HP-20 column and the column was washed with $\mathrm{H}_{2} \mathrm{O}$ followed by elution with $\mathrm{MeOH}$. The $\mathrm{MeOH}$ eluate was subjected to HPLC to give products.

Spectral data of a new compound, 2-(4- $\beta$-gentiobiosyloxphenyl)-2-(4- $\beta$-D-glucopyranosyloxyphenyl)propane (5): FAB MS: $m / z 737[\mathrm{M}+\mathrm{Na}]^{+} ;{ }^{1} \mathrm{H}$ NMR (400 MHz, $\mathrm{CD}_{3} \mathrm{OD}, \delta$ in ppm): $\delta 1.60$ (s, 6H, H-1, 3), 3.25-3.90 (m, 18H, H-2', 3', 4', 5', 6', 2", 3", 4", 5", 6", 2"', 3"', 4"', 5"', 6"'), 4.50 (d, 1H, J=7.6 Hz, H-1"'), 4.86 (d, 1H, J=8.0 Hz, H-1'), 4.87 (d, 2H, $\left.J=8.0 \mathrm{~Hz}, \mathrm{H}-1^{\prime \prime}\right), 6.95$ (d, 2H, $J=8.5$ $\mathrm{Hz}, \mathrm{H}-12,14), 7.00$ (d, 2H, $J=8.5 \mathrm{~Hz}, \mathrm{H}-6,8), 7.12$ (d, $2 \mathrm{H}, J=8.5 \mathrm{~Hz}, \mathrm{H}-11,15), 7.15$ (d, 2H, $J=8.5 \mathrm{~Hz}, \mathrm{H}-5$, 9); ${ }^{13} \mathrm{C}$ NMR $\left(\mathrm{CD}_{3} \mathrm{OD}\right): \delta 31.5$ (C-1, C-3), 42.9 (C-2), 62.3, 62.5 (C-6', C-6"'), 68.8 (C-6"), 71.2, 71.5 (C-4', C-4", C-4"'), 75.0, 75.1 (C-2', C-2", C-2"'), 77.7, 78.0, 78.1 (C-3', C-3", C-3"'), 78.2, 78.3, 78.8 (C-5', C-5", C-5"'), 102.5 (C-1', C-1"), 105.1 (C-1"'), 117.0 (C-12, C-14), 117.2 (C-6, C-8), 128.1 (C-11, C-15), 128.7 (C-5, C-9), 146.1 (C-10), 146.8 (C-4), 157.0 (C-13), 157.6 (C-7).

\subsection{Preparation of Immobilized A. crassum and C. roseus in Sodium Alginate Gel}

Sodium alginate $(2 \%)$ was suspended in water $(500 \mathrm{ml})$, which was autoclaved at $120^{\circ} \mathrm{C}$ for $30 \mathrm{~min}$. The cultured cells in the stationary growth phase have been used for experiments. Cultured cells of $A$. crassum $(9 \mathrm{~g})$ and $C$. roseus $(70 \mathrm{~g})$ were individually added to this solution and the mixture was stirred for $2 \mathrm{~h}$ until it became homogeneous. The suspension was added dropwise from a dropping funnel with a glass tube into a $5 \% \mathrm{CaCl}_{2}$ solution (1 1) with stirring to form pieces of spherical sodium alginate gel with $5 \mathrm{~mm}$ diameter immediately. Washing with water gave each immobilized cells of $A$. crassum and $C$. roseus which were used for biotransformation of bisphenol A.

\subsection{Time Course Experiments}

Time course experiments to examine the biotransforma- 
tion of bisphenol A by A. crassum were carried out using eight flasks containing cultured cells $(9 \mathrm{~g})$ or immobilized cells, which included $9 \mathrm{~g}$ cells. In the case of the biotransformation by the cultured and immobilized $C$. roseus cells, cultured cells ( $70 \mathrm{~g})$ or immobilized cells, which included $70 \mathrm{~g}$ cells, were partitionated to each flask. Substrate $(0.2 \mathrm{mmol})$ was administered to each of flasks and the mixtures were incubated on a rotary shaker at $25^{\circ} \mathrm{C}$. At a day interval, one of the flasks was taken out from the rotary shaker, and the cells (or immobilized cells) and medium were separated by filtration. The extraction and analysis procedures were same as described above. The yield of the products was determined on the basis of the peak area from HPLC and expressed as a relative percentage to the total amount of the whole reaction products extracted.

\section{Results and Discussions}

The biotransformation product was isolated from $A$. crassum cell cultures, which had been incubated with bisphenol A (1) for five days, by a combination of Diaion HP-20 column chromatography and preparative HPLC in $4 \%$ yield. The glycosylation product 2 was detected by HPLC. No additional conversion products were observed in spite of careful analyses by HPLC. Incubation of the substrate in medium without cells gave no transformation products. The structure of the product $\mathbf{2}$ was determined as 2-(4- $\beta$-D-glucopyranosyloxyphenyl)-2-hydroxyphenylpropane (bisphenol A glucoside) by FABMS, ${ }^{1} \mathrm{H}$ and ${ }^{13} \mathrm{C}$ NMR analyses (Figure 1). To investigate the biotransformation pathway, the time course in the conversion of 1 was followed. Figure 2 showed that the amount of product 2 increased with time during the reaction with cultured A. crassum cells.

Next, A. crassum cells were immobilized with sodium alginate at concentrations of $2 \%$. The immobilized $A$. crassum cells were incubated with bisphenol A (1) for five days. The product 2 was obtained in $6 \%$ yield. The time course of the conversion of bisphenol A (1) with immobilized A. crassum cells was investigated. As shown in Figure 3, the glycosylation activity for bisphenol A (1) was increased and the compound $\mathbf{2}$ was produced in higher yield in comparison with the case of the biotransformation using normal cells.

On the other hand, four biotransformation products 2-5 were isolated by a combination of Diaion HP-20 column chromatography and preparative HPLC after five days incubation of cultured plant cells of $C$. roseus with bisphenol A (1). The yields of $\mathbf{2 - 5}$ were 5, 12, 8, and 2\%. The structures of the products 3-6 were identifined as 2,2-bis(4- $\beta$-D-glucopyranosyloxyphenyl)propane (diglucoside, 3), 2-(4- $\beta$-genbiobiosyloxyphenyl)-2-(4hydroxyphenyl) propane (gentiobioside, 4), and 2-(4- $\beta$ gentiobiosylophenyl)-2-(4- $\beta$-D-glucopyranosyloxyphenyl) propane (gentiobiosylglucoside, 5) (Figure 4). The

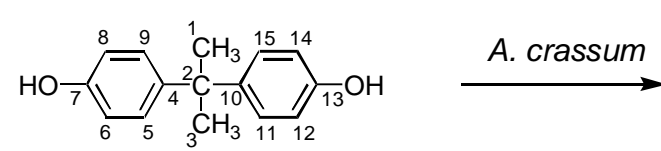

Bisphenol A (1)

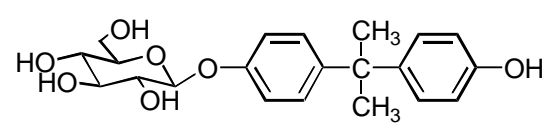

2

Figure 1. Glycosylation of bisphenol A (1) by cultured cells of A. crassum.

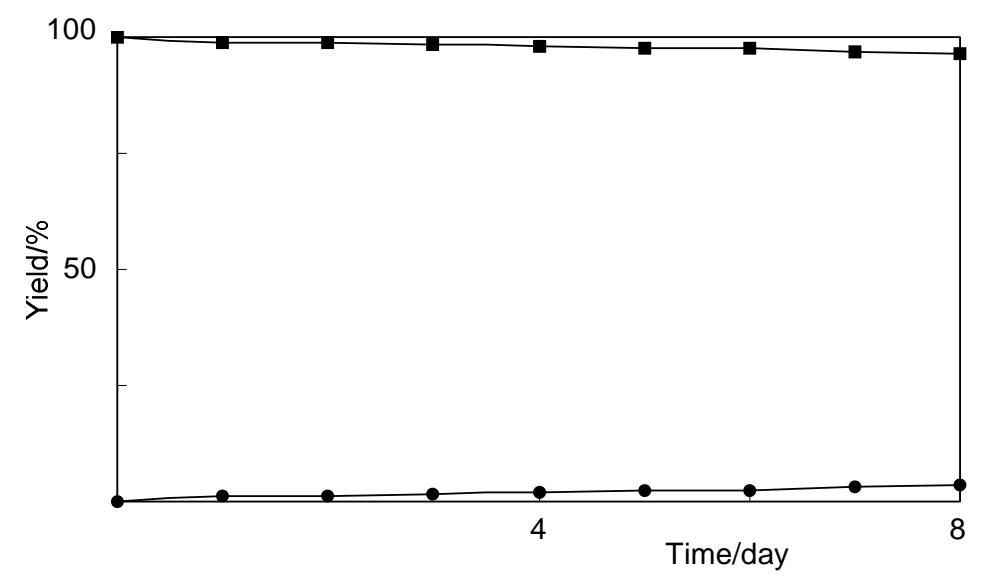

Figure 2. Time course of the glycosylation of bisphenol A (1) by the cultured cells of A. crassum. Yields of 1 ( $(\bullet)$ and 2 (•) are plotted. 


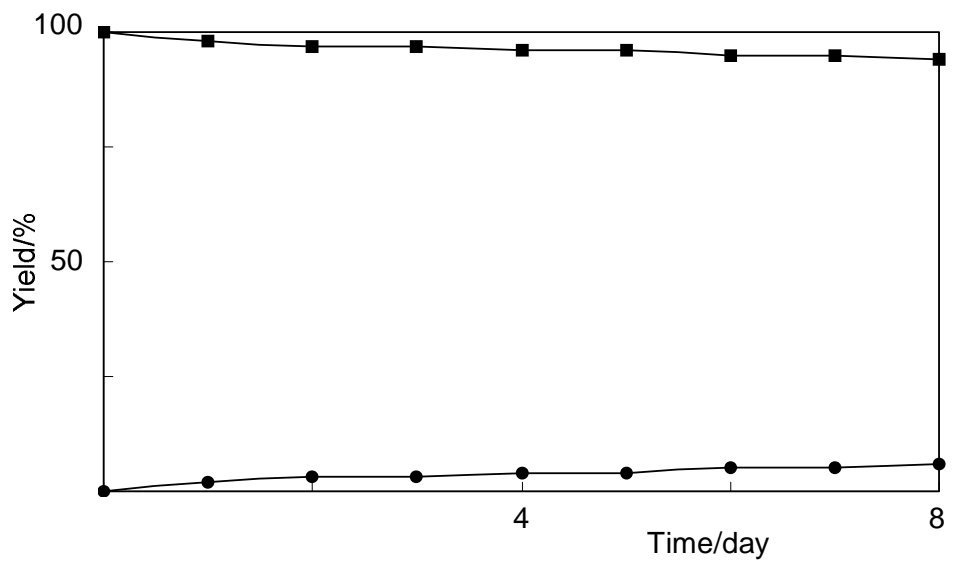

Figure 3. Time course of the glycosylation of bisphenol A (1) by the immobilized cells of A. crassum. Yields of 1 ( $\square)$ and 2 (•) are plotted.

product 5 was a new compound. To investigate the biotransformation pathway, the time course in the conversion of 1 by cultured C. roseus cells was examined. Products 2, 3, and $\mathbf{4}$ were produced at an early stage of incubation. On the other hand, 5 was accumulated after 3 days of incubation (Figure 5). These findings indicated that $\mathbf{1}$ was first converted to 2-4 and further glycosylation gave $\mathbf{5}$ as shown in Figure 4.
Immobilized $C$. roseusm cells were tested for their ability to convert bisphenol A (1). The substrate, bisphenol A (1), was converted into products $\mathbf{2 - 5}$ in 7, 17, 11, and $4 \%$ yields by five days incubation. The time course of the conversion of bisphenol A (1) with immobilized A. crassum cells was investigated. As shown in Figure 6, the products 2-5 were obtained in higher yields in comparison with the case of the biotransformation using nor-



Figure 4. Glycosylation of bisphenol A (1) by cultured cells of $C$. roseus.

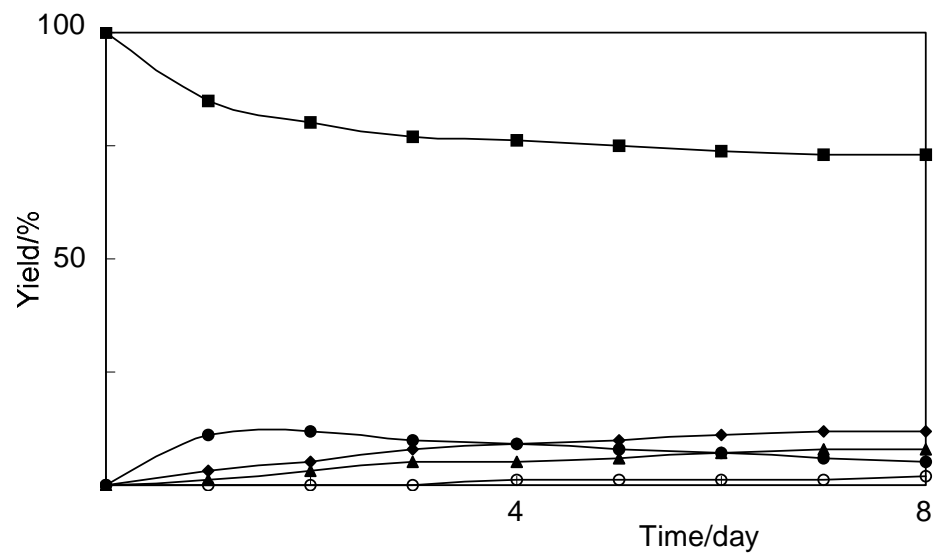

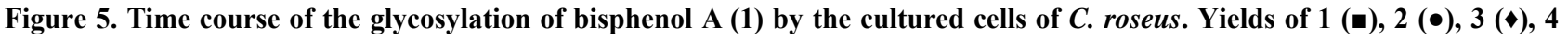
$(\Delta)$, and $5(\circ)$ are plotted. 


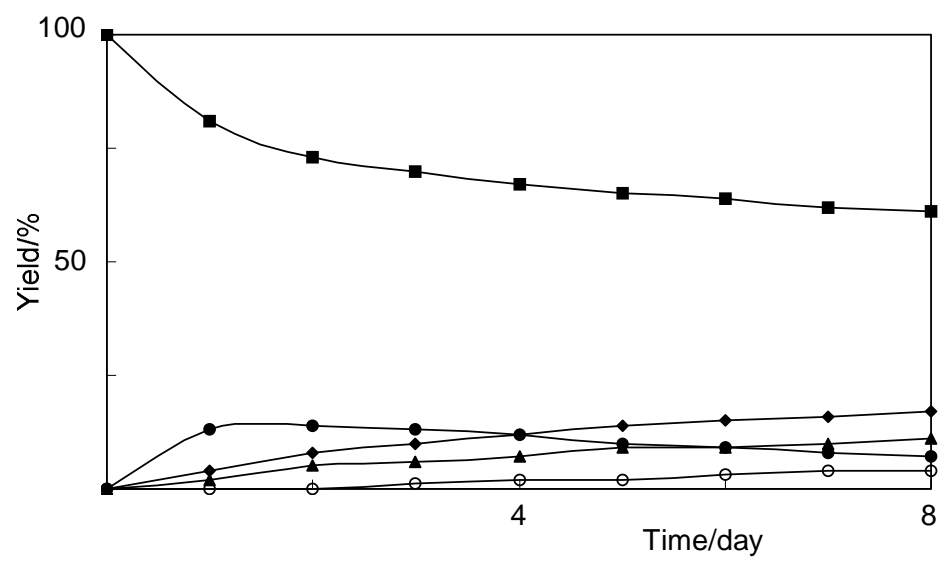

Figure 6. Time course of the glycosylation of bisphenol A (1) by the immobilized cells of C. roseus. Yields of $1(\square), 2(\bullet), 3(\bullet)$, $4(\Delta)$, and $5(\circ)$ are plotted.

mal cells.

The results of this experiment demonstrate that cultured marine microalga of $A$. crassum converted bisphenol A into its glucoside and that cultured plant cells of $C$. roseus glycosylate bisphenol A to its glucoside, diglucoside, gentiobioside, gentiobiosylglucoside. The use of immobilized cells of both $A$. crassum and $C$. roseus in sodium alginate gel much improved the yield of the products.

Recently, it has been reported that freshwater microalga of Pseudokirchneriella subcapitata, Scenedesmusacutus, and Coelastrum reticulatum converted bisphenol A into its glucoside [19]. Also, bisphenol A was shown to be transformed to its glucoside, diglucoside, gentiobioside, and trisaccharide, i.e., $O-\beta-\mathrm{D}-$ glucopysyl- $(1 \rightarrow 4)$ - $[\beta$-D-glucopyranosyl- $(1 \rightarrow 6)] \beta-D-$ glucopyranoside, by cultured plant cells of Nicotiana tabacum [20]. On the other hand, recent paper revealed that estrogenicity of bisphenol A was eliminated by formation of the diglucoside and that reduced activity remained in the glucoside [18]. These studies demonstrate that metabolism of bisphenol A by freshwater microalga and plants offers the possibility of bioremediation of contaminated water. The present study showed that immobilized marine microalga of $A$. crassum and plant cells of $C$. roseus are useful bioreactors for bioremediation of bisphenol A, which is an environmental pollutant released into seas and rivers. Studies of the physiological activities of bisphenol A glycosides, such as gentiobioside and gentiobiosylglucoside, are now in progress.

\section{Acknowledgements}

This work was supported by grant from The Salt Science Research Foundation, No. 1105.

\section{References}

[1] D. Seidlová-Wuttke, H. Jarry, J. Christoffel, G. Rimoldi and W. Wuttke, "Effects of Bisphenol-A (BPA), Dibutylphtalate (DBP), Benzophenone-2 (BP2), Procymidone (Proc), and Linurone (Lin) on Fat Tissue, a Variety of Hormones and Metabolic Parameters: A 3 Months Comparison with Effects of Estradiol (E2) in Ovariectomized (ovx) Rats," Toxicology, Vol. 213, No. 1-2, 2005, pp. 13-24. doi:10.1016/j.tox.2005.05.001

[2] G. Pojana, A. Gomiero, N. Jonkers and A. Marcomini, "Natural and Synthetic Endocrine Disrupting Compounds (EDCs) in Water, Sediment and Biota of a Coastal Lagoon," Environment International, Vol. 33, No. 7, 2007, pp. 929-936. doi:10.1016/j.envint.2007.05.003

[3] L. Yuan, G. M. Zeng, C. Zhang, J. Yu and J. M. Xu, "Isolation, Identification and Degradation Characteristics of Bisphenol a Degrading Strain," Huanjing Kexue, Vol. 27, No. 10, 2006, pp. 2095-2099.

[4] T. Iwasaki, K. Miyauchi, E. Masai and M. Fukuda, "Multiple-Subunit Genes of the Aromatic-Ring-Hydroxylating Dioxygenase Play an Active Role in Biphenyl and Polychlorinated Biphenyl Degradation in Rhodococcus sp. Strain RHA1," Applied and Environmental Microbiology, Vol. 72, No. 8, 2006, pp. 5396-5402. doi:10.1128/AEM.00298-06

[5] H. Yamanaka, K. Moriyoshi, T. Ohmoto, T. Ohe and K. Sakai, "Degradation of Bisphenol A by Bacillus Pumilus Isolated from Kimchi, a Traditionally Fermented Food," Applied Biochemistry and Biotechnology, Vol. 136, No. 1, 2007, pp. 39-51. doi:10.1007/BF02685937

[6] L. Y. Jia, A. P. Zheng, L. Xu, X. D. Huang, Q. Zhang and F. L. Yang, "Isolation and Characterization of Comprehensive Polychlorinated Biphenyl Degrading Bacterium, Enterobacter sp. LY402," Journal of Microbiology and Biotechnology, Vol. 18, No. 5, 2008, pp. 952-957.

[7] T. Artham and M. Doble, "Biodegradation of Aliphatic and Aromatic Polycarbonates," Macromolecular Bioscience, Vol. 8, No. 1, 2008, pp. 14-24. doi:10.1002/mabi.200700106 
[8] H. Yamanaka. K. Moriyoshi, T. Ohmoto, T. Ohe and K. Sakai, "Efficient Microbial Degradation of Bisphenol A in the Presence of Activated Carbon," Journal of Bioscience and Bioengineering, Vol. 105, No. 2, 2008, pp. 157-160. doi:10.1263/jbb.105.157

[9] E. Lewinson, E. Berman, Y. Mazur and J. Gressel, "Glucosylation of Exogenous Flavanones by Grapefruit (Citrus paradisi) Cell Cultures," Phytochemistry, Vol. 25, No. 11, 1986, pp. 2531-2535.

[10] M. Tabata, Y. Umetani, M. Ooya and S. Tanaka, "Glucosylation of Phenolic Compounds by Plant Cell Cultures," Phytochemistry, Vol. 27, No. 11, 1988, pp. 809813. doi:10.1016/0031-9422(88)84097-4

[11] B. Upmeier, J. E. Thomzik and W. Barz, "Nicotinic Acid$\mathrm{N}$-Glucoside in Heterotrophic Parsley Cell Suspension Cultures," Phytochemistry, Vol. 27, No. 11, 1988, pp. 3489-3493. doi:10.1016/0031-9422(88)80754-4

[12] T. Furuya, M. Ushiyama, Y. Ashida and T. Yoshikawa, "Biotransformation of 2-Phenylpropionic Acid in Root Culture of Panax Ginseng," Phytochemistry, Vol. 28, No. 2, 1989, pp. 483-487. doi:10.1016/0031-9422(89)80036-6

[13] M. Ushiyama, T. Asada, T. Yoshikawa and T. Furuya, "Biotransformation of Aromatic Carboxylic Acids by Root Culture of Panax Ginseng," Phytochemistry, Vol. 28, No. 7, 1989, pp. 1859-1869. doi:10.1016/S0031-9422(00)97875-0

[14] S. Kwon, K. Shimoda, H. Hamada, K. Ishihara, N. Masuoka and H. Hamada, "High Production of $\beta$-Thujaplicin Glycosides by Immobilized Plant Cells of Nicotiana Tabacum," Acta Biologica Hungarica, Vol. 59, No. 3, 2008, pp. 347-355.

[15] H. Katsuragi, K. Shimoda, A. Ohiro and H. Hamada, "Glycosylation of Capsaicinoids with Panax Ginseng Stimulated by Salicylic Acid," Acta Biologica Hungarica, Vol. 61, No. 4, 2010, pp. 449-456. doi:10.1556/ABiol.61.2010.4.8

[16] T. Suga and T. Hirata, "Biotransformation of Exogenous Substrates by Plant Cell Cultures," Phytochemistry, Vol. 29, No. 8, 1990, pp. 2393-2406. doi:10.1016/0031-9422(90)85155-9

[17] K. Ishihara, H. Hamada, T. Hirata and N. Nakajima, "Biotransformation Using Plant Cultured Cells," Journal of Molecular Catalysis B: Enzymatic, Vol. 23, No. 2-6, 2003, pp. 145-170. doi:10.1016/S1381-1177(03)00080-8

[18] K. Morohoshi, F. Shiraishi, Y. Oshima, T. Koda, N. Nakajima, J. S. Edmonds and M. Morita, "Synthesis and Estrogenic Activity of Bisphenol a Mono- and di-beta-DGlucopyranosides, Plant Metabolites of Bisphenol A," Environmental Toxicology and Chemistry, Vol. 22, No. 10, 2003, pp. 2275-2279. doi:10.1897/02-464

[19] N. Nakajima, T. Teramoto, F. Kasai, T. Sano, M. Tamaoki, M. Aono, A. Kubo, H. Kamada, Y. Azumi and H. Saji, "Glycosylation of Bisphenol A by Freshwater Microalgae," Chemosphere, Vol. 69, No. 6, 2007, pp. 934-941. doi:10.1016/j.chemosphere.2007.05.088

[20] N. Nakajima, Y. Oshima, J. S. Edmonds and M. Morita, "Glycosylation of Bisphenol A by Tobacco BY-2 Cells," Phytochemistry, Vol. 65, No. 10, 2004, pp. 1383-1387. doi:10.1016/i.phytochem.2004.02.027 